\title{
MATHEMATICAL MODEL FOR SOLVING OPERATIONAL PROBLEM OF REGIONAL CARGO TRANSPORTATION
}

A. V. Panyukov ${ }^{1}$, paniukovav@susu.ru,

Yu.V. Pivovarova ${ }^{1}$, pivovarova.jul@mail.ru,

Kh. Z. Chaloob ${ }^{1}$, khalid.e@mail.ru

${ }^{1}$ South Ural State University, Chelyabinsk, Russian Federation

The task of operatively to provide cargo transportation with the given kinds of available vehicles is actual at operative planning of work of logistic centres. In the case of non-transit transporting planning, the amount of available vehicles is critical, which in some cases does not allow the fulfilment of orders to the full extent. The use of transit transport allows to reduce the volume of unfulfilled orders. The article presents a formal setting of the given problems in the form of multi-index problems of linear programming. Special cases of problems, which allow to use effective algorithms for their solution, are noted.

Keywords: transport logistics; distribution task; transport task; graph; incident matrix; linear programming.

\section{Introduction}

The task of operatively to provide cargo transportation with the given kinds of available vehicles is actual at operative planning of work of logistic centers [1].

Let $J$ be a set of logistics centers, $R$ be a set of kinds of goods, $K$ be a set of vehicle modes. Let us consider set of possible communications $D=\{(i, j): i, j \in J, i \neq j\}$. Let there be $\lambda^{r k}$ a generalized specific volume required for transportation of the unit of the product $r \in R$ on the transport of the species $k \in K$, let there $R_{i j}^{k}$ be a allowable no-transit volume of transportation from the center $i \in I$ to the center $j \in J$ by transport $k \in K$. Thus, if the amount $x_{i j}^{r k}$ of non-transit traffic from center $i \in I$ to center $j \in J$ of the product $r \in R$ with vehicle kind $k \in K$, then it is necessary to implement the restriction

$$
\sum_{r \in R} \lambda^{r k} x_{i j}^{r k} \leqslant R_{i j}^{k}, \quad(i, j) \in D, \quad k \in K
$$

Let $E_{i j}^{r}$ be volume of the order for transportation of the product $r \in R$ from the center $i \in J$ to the center $j \in J$, i.e. the volumes $x_{i j}^{r k}$ of transit-free shipments of a product $r \in R$ must satisfy the condition

$$
E_{i j}^{r}=e_{i j}^{r}+\sum_{k \in K} x_{i j}^{r k}, \quad(i, j) \in D, \quad r \in R,
$$

where $e_{i j}^{r} \geq 0$ is an unsatisfied part of the demand, since in the general case the system of constraints (1)-(2) may be inconsistent if $e_{i j}^{r}=0$ for all $r \in R$.

Although an unmet part of the current demand can be met in the next planning period, an enterprise pays a penalty

$$
P_{i j}=\sum_{r \in R} c_{i j}^{r} e_{i j}^{r}, \quad(i, j) \in D
$$


The foregoing demonstrates the possibility of scheduling off-transit traffic on a route $(i, j) \in D$ by solving the distribution problem [2], [3] of linear programming

$$
\min _{x, e}\left\{\begin{array}{l|l}
\sum_{r \in R} c_{i j}^{r} e_{i j}^{r} & \begin{array}{c}
\sum_{r \in R} \lambda^{r k} x_{i j}^{r k} \leqslant R_{i j}^{k}, \quad k \in K ; \\
\sum_{k \in K} x_{i j}^{r k}+e_{i j}^{r}=E_{i j}^{r}, \quad r \in R ; \\
x \geqslant 0, \quad e \geqslant 0
\end{array}
\end{array}\right\}, \quad(i, j) \in D .
$$

The problem (4) for each unbound rote $(i, j) \in D$ has $|R| \cdot|K|+|R|$ variables and $|K|+|R|$ restrictions for non-negative variables.

If for all $k \in K$ and $r \in R$ we have equation

$$
\lambda^{r k}=\alpha_{r} \beta_{k}
$$

then the change of variables $\alpha_{r} x_{i j}^{r k}=y_{i j}^{r k}, \alpha_{r} e_{i j}^{r}=f_{i j}^{r}$ allows us to pass from problem (4) to problem

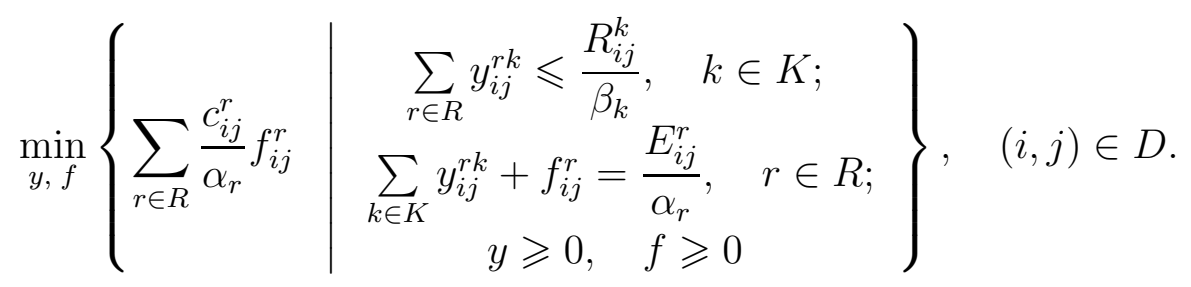

The problem (6) is known as a transportation problem in a matrix setting [2]. Effective algorithms are known for its solution [4].

\section{Reducing Volume of Unfulfilled Orders by Transit Transport}

To reduce the total amount of penalty

$$
P=\sum_{(i, j) \in D} P_{i j}=\sum_{(i, j) \in D}\left(\sum_{r \in R} c_{i j}^{r} e_{i j}^{r}\right)
$$

one may introduce transit routes. So, let us define for every $(i, j) \in D$ a set of

$$
D(i, j)=\{l \in J:(i, l),(l, j) \in D\}
$$

logistics centers, through which a transit route is possible $(i, l, j):(i, l),(l, j) \in D$.

Let $z_{i l j}^{r}$ be the amount of a product $r \in R$, transferred from the route $(i, j) \in D$ to the transit route $(i, l, j)$. In the case of the possibility of transit transporting the analogue of the equation (2) of the balance between the transport order $E_{i j}^{r}$ and the volumes of transporting $x_{i j}^{r k} \geqslant 0$ is the equation

$$
E_{i j}^{r}+\sum_{l: i \in D(l, j)} z_{l i j}^{r}-\sum_{l \in D(i, j)} z_{i l j}^{r}=e_{i j}^{r}+\sum_{k \in K} x_{i j}^{r k}, \quad(i, j) \in D, \quad r \in R .
$$

In (9) the volume of the order is modified by including the transit volumes from the more remote points (the first amount) in the route $(i, j) \in D$, and the excluding the transit volumes through less remote points (the second amount). 
Expansion of the task (4) of planning taking into account transit transportation has a form

$$
\min _{z, x, e}\left\{\sum_{(i, j) \in D}\left(\sum_{r \in R} c_{i j}^{r} e_{i j}^{r}\right) \mid \begin{array}{c}
\sum_{r \in R} \lambda^{r k} x_{i j}^{r k} \leqslant R_{i j}^{k}, \quad k \in K,(i, j) \in D ; \\
E_{i j}^{r}+\sum_{l: i \in D(l, j)} z_{l i j}^{r}-\sum_{l \in D(i, j)} z_{i l j}^{r}=e_{i j}^{r}+\sum_{k \in K} x_{i j}^{r k}, \\
z \geqslant 0, \quad x \geqslant 0, \quad e \geqslant 0 .
\end{array}\right\}
$$

Problem (10) is multi-index transport problem, special variants of the simplex-method are known for its solution [2].

\section{Special Cases}

If for all $k \in K$ and $r \in R$ there is equality (5), then the change of variables

$$
\alpha_{r} x_{i j}^{r k}=y_{i j}^{r k}, \quad \alpha_{r} e_{i j}^{r}=f_{i j}^{r}, \quad \alpha_{r} z_{i j}^{r}=\zeta_{i j}^{r}
$$

makes it possible to pass from problem (10) to problem

$$
\min _{\zeta, y, f}\left\{\sum_{(i, j) \in D}\left(\sum_{r \in R} \frac{c_{i j}^{r}}{\alpha_{r}} f_{i j}^{r}\right) \mid \begin{array}{c}
-\sum_{r \in R} y_{i j}^{r k} \geqslant-\frac{R_{i j}^{k}}{\beta_{k}}, \quad k \in K,(i, j) \in D \\
f_{i j}^{r}+\sum_{k \in K} y_{i j}^{r k}-\sum_{\substack{l: i \in D(l, j) \\
l i j}} \zeta_{\substack{l \in D(i, j) \\
(i, j)}} \zeta_{i l j}^{r}=\frac{E_{i j}^{r}}{\alpha_{r}}, r \in R \\
\zeta \geqslant 0, \quad y \geqslant 0, \quad f \geqslant 0 .
\end{array}\right\}
$$

Theorem 1. The restriction matrix of problem (11) is the incident matrix of an digraph $G$ with a set of vertices

$$
V(G)=V_{K}(G) \cup V_{R}(G), \quad V_{K}(G)=(K \times D), \quad V_{R}(G)=(R \times D)
$$

and a set of arcs

$$
\begin{aligned}
& G: E(G)=E_{K R}(G) \cup E_{R R}(G), \quad E_{K R}(G)=((K \times D) \times(R \times D)), \\
& E_{R R}(G)=\{R \times\{((i, j),(l, j)):(i, j) \in D,(l, j) \in D\}\} .
\end{aligned}
$$

Proof.

It $\mathrm{s}$ obvious there is one-to-one correspondence between the vertices $\langle(i, j) \in D, k \in K\rangle$ of digraph $G$ and the constraints of the first group of problem (11), as well as between the vertices $\langle(i, j) \in D, r \in R\rangle$ of digraph $G$ and the constraints of the second group of problem (11). Thus, a one-to-one correspondence is established between the vertices of graph $G$ and the rows of the constraint matrix of problem (11).

Let $i, j, l \in J, \quad r \in R$. Non-zero elements of the constraint matrix corresponding to variables $z_{\pi}^{r}, r \in R, \pi$ is permutation of mutually distinct fixed $i, j, l \in J$, are given in Table 1.

From the table we see that for any $r \in R$ and any mutually distinct $i, j, l \in J$ variable $z_{i j l}^{r}$ can be treated as a flow along an arc $\langle r,((i, l),(j, l))\rangle \in E_{R R}$. Thus, z-submatrix 
Table 1

The fragment of the incidence matrix of graph $G$

\begin{tabular}{|c|c|c|c|c|c|c|}
\hline Restric- & \multicolumn{6}{|c|}{ Variables / Arcs } \\
\hline $\begin{array}{l}\text { tions / } \\
\text { Nodes }\end{array}$ & $\begin{array}{c}z_{l i j}^{r} / \\
\left\langle\begin{array}{l}(l, j) \\
r, \\
(i, j)\end{array}\right\rangle\end{array}$ & $\begin{array}{c}z_{i l j}^{r} / \\
\left\langle\begin{array}{l}(i, j) \\
r, \\
(l, j)\end{array}\right\rangle\end{array}$ & $\begin{array}{c}z_{i j l}^{r} / \\
\left\langle\begin{array}{l}(i, l) \\
r, \\
(j, l)\end{array}\right\rangle\end{array}$ & $\begin{array}{c}z_{l j i}^{r} / \\
\left\langle\begin{array}{l}(l, i) \\
r, \\
(j, i)\end{array}\right\rangle\end{array}$ & $\begin{array}{c}z_{j l i}^{r} / \\
\left\langle\begin{array}{c}(j, i) \\
r, \\
(l, i)\end{array}\right\rangle\end{array}$ & $\begin{array}{c}z_{j i l}^{r} / \\
\left\langle\begin{array}{l}(j, l) \\
r, \\
(i, l)\end{array}\right\rangle\end{array}$ \\
\hline$\langle r,(i, j)\rangle$ & 1 & -1 & 0 & 0 & 0 & 0 \\
\hline$\langle r,(j, i)\rangle$ & 0 & 0 & 0 & 1 & -1 & 0 \\
\hline$\langle r,(i, l)\rangle$ & 0 & 0 & -1 & 0 & 0 & 1 \\
\hline$\langle r,(l, i)\rangle$ & 0 & 0 & 0 & -1 & 1 & 0 \\
\hline$\langle r,(j, l)\rangle$ & 0 & 0 & 1 & 0 & 0 & -1 \\
\hline$\langle r,(l, j)\rangle$ & -1 & 1 & 0 & 0 & 0 & 0 \\
\hline
\end{tabular}

(containing only the columns corresponding to the variables of the group $z$ ) of the matrix of problem (11) is the incidence matrix of subgraph $G\left(V_{R}(G)\right)$. It is obvious that this subgraph contains all arcs from the set $E_{R R}$ and only them.

It is easy to see that $y$-submatrix is the incidence matrix of subgraph $H\left(E_{K R}\right)$ of digraph $G$ for all arcs from the set of arcs $E_{K R}$, that are not included into subgraph $G\left(V_{R}(G)\right)$. By construction digraph $G$ and its incidence matrix are the junction of digraphs $G\left(V_{R}(G)\right), H\left(E_{K R}\right)$ and their incidence matrices respectively. The theorem is proved.

As is known, the incidence matrix of the oriented graph is absolutely unimodular [5]. Consequently, problem (11) has an integral-valued optimal solution at integrality of the right part of its system of constraints. Paper [4] presents effective algorithms to find an integral-valued optimal solution for problems of high dimension.

The work was supported by Act 211 Government of the Russian Federation, contract no. 02.A03.21.0011.

\section{References}

1. Panyukov A. V., Pivovarova Yu. V. Development of Transport Logistics in the Chelyabinsk Region: Problems and the Prospects of Using Information Technologies. Bulletin of the South Ural State University. Series: Economics and Management, 2017, vol. 11, no. 1, pp. 7-11. DOI: 10.14529/em170101. (in Russian)

2. Raskin L. G., Kirichenko I. O. [Multiindex Linear Programming Problems], Moscow, Radio i Svyaz' Publ., 1982. (in Russian)

3. Sira O. V. Distribution Linear Programming Problem. Information Processing Systems, 2013, no. 2 (109), pp. 167-170. (in Russian)

4. Panyukov A. V., Teleghin V. A. Software Engineering of the Flow Algorithms. Bulletin of the South Ural State University. Series: Mathematical Modelling, Programming and Compute Software, 2008, № 27 (127), issue 2, pp. 78-99. (in Russian) 
5. Emelichev V. A., Kovalev M. M., Kravtsov M. K. Polytopes, Graphs and Optimization. New York, Cambridge University Press, 1984.

Anatoly V. Panyukov, DSc (Math), Professor, Department of Mathematical and Computer Modeling, South Ural State University (Chelyabinsk, Russian Federation), paniukovav@susu.ru.

Yulia V. Pivovarova, Student, Department of Mathematical and Computer Modeling, South Ural State University (Chelyabinsk, Russian Federation), pivovarova.jul@mail.ru.

Khalid Z. Chaloob, Postgraduate Student, Department of Mathematical and Computer Modeling, South Ural State University (Chelyabinsk, Russian Federation), khalid.e@mail.ru.

\title{
МАТЕМАТИЧЕСКАЯ МОДЕЛЬ ДЛЯ РЕШЕНИЯ ОПЕРАТИВНОЙ ПРОБЛЕМЫ РЕГИОНАЛЬНЫХ ГРУЗОПЕРЕВОЗОК
}

\author{
А. В. Панюков, Ю. В. Пивоварова, Х. З. Чалуб
}

При оперативном планировании работы логистических центров актуальной является задача оперативного обеспечения грузоперевозок заданных объемов различных товаров при заданных количествах различных транспортных средств. В случае планирования безтранзитных перевозок критичным является объем имеющихся транспортных средств, что в ряде случаев не позволяет выполнить заказы в полном объеме. Уменьшить объем невыполненных заказов позволяет использование транзитных перевозок. В статье дана формальная постановка указанных проблем в виде многоиндексных задач линейного программирования. Отмечены частные случаи задач, позволяющие использовать для их решения эффективные алгоритмы.

Ключевые слова: транспортная логистика; распределительная задача; транспортная задача; граф; матрица инцидентности; линейное программирование.

\section{Литература}

1. Панюков, А. В. Развитие транспортной логистики в Челябинской области: проблемы и перспективы применения информационных технологий / А. В. Панюков, Ю. В. Пивоварова // Вестник ЮУрГУ. Серия: Экономика и менеджмент. - 2017. T. 11, № 1. - C. 7-11.

2. Раскин, Л. Г. Многоиндексные задачи линейного программирования / Л. Г. Раскин, И. О. Кириченко. - М.: Радио и связь, 1982.

3. Серая, О. В. Распределительная задача линейного программирования / О. В. Серая // Системы обработки информации. - 2013. - № 2 (109). - С. 167-170. 
4. Панюков, А. В. Техника программной реализации потоковых алгоритмов / А. В. Панюков, В. А. Телегин // Вестник ЮУрГУ. Серия: Математическое моделирование и программирование. - 2008. - Т. 27 (127), вып. 2. - С. 78-99.

5. Емеличев, В. А. Многогранники, графы, оптимизация / В. А. Емеличев, М. М. Ковалев, М. К. Кравцов. - М.: Наука, 1981.

Панюков Анатолий Васильевич, доктор физико-математических наук, профессор, профессор кафедры математического и компъютерного моделирования, Южн-Уральский государственный университет (Челябинск, Российская Федераu,я), paniukovav@susu.ru.

Пивоварова Юлия Валеръевна, студент кафедры математического и компъютерного моделирования, Южно-Уральский государственный университет (Челябинск, Российская Федерация), pivovarova.jul@mail.ru.

Чалуб Халид, аспирант кафедры математического и компьютерного моделирования, Южно-Уральский государственный университет (Челябинск, Российская Федераuия),khalid.e@mail.ru.

Поступила в редакиию 9 марта 2018 г. 